\title{
Multi-Dimensional Analysis of Quality Parameters of Issyk-Kul Lake
}

\author{
Aliyaskarov Mail ${ }^{1 *}$, Sarieva Mayram $^{2}$ and Djenbaev Bekmamat Murzakmatoviç ${ }^{3}$ \\ ${ }^{1}$ Department of Pasture, Livestock and Fisheries of the Ministry of Agriculture, Russia \\ ${ }^{2}$ FAO UN project, Kyrgyz Republic, Russia \\ ${ }^{3}$ National Academy of Sciences of the Kyrgyz Republic, Kyrgyz Republic, Russia
}

Submission: March 26, 2019; Published: April 22, 2019

Corresponding author: Aliyaskarov Mail, Department of Pasture, Livestock and Fisheries of the Ministry of Agriculture, Russia

\begin{abstract}
Annotation
This scientific article carries out a multi-dimensional analysis of the water quality of Issyk-Kul Lake. Materials and results of the study conducted in 2014-2015 using the MINITAB statistical method (version 16) provided with an opportunity to determine the productive zones of Issyk-Kul Lake by sites. The results of the study show that Issyk-Kul Lake belongs to the group of an alkaline water body, where the average $\mathrm{pH}$ comprises 8-9. The total mineralization of the lake's water contains from 3.4 to $4.3 \mathrm{mg} / \mathrm{l}$, according to V.I. Vernadsky's classification, IssykKul Lake is considered a brackish body of water. As per the classification of P.F. Domrachev, Issyk-Kul Lake is a warm water body, wherein summertime the average integral water temperature of Issyk-Kul Lake ranges from 17.2 to 22.1 degrees Celsius [1]. Air temperature above 15 degrees Celsius in the Issyk-Kul region is 106-120 days a year [2].
\end{abstract}

Keywords: Issyk-Kul; PCA- principal component analysis; Electrical conductivity; Mineralization; Water transparency; Chlorophyll-a; Urbanization

\section{Relevance}

In the modern world, an increase in population growth is accompanied by intense urbanization. This process in addition to the positive aspects, it has several negative consequences, such as environmental change, air pollution, reduction of surface and groundwater, as well as other processes affecting natural resources. The pace of infrastructure development does not keep pace with the rate of population growth in the world [3]. The Kyrgyz Republic is a landlocked country, but with a large variety of inland water resources, the sources are fully formed on their own territory [4]. The beautiful Issyk-Kul Lake is located on the territory of the Kyrgyz Republic, which is currently attracting more and more attention as a recreation area. Lake Issyk-Kul is a drainless, high-altitude lake of tectonic origin [5].

The change in the trophic state of reservoirs has become a serious global environmental problem throughout the world. With an increase in population size and an increase in the anthropogenic impact on water resources, the trophic state of water bodies deteriorates, this increases the productivity of lakes, and eutrophication processes become global [6]. Hydrological cycles affect the microclimate, enhancing the aesthetic beauty of the landscape, providing recreational opportunities for all of humanity. Currently, with the increase in the productivity of aquatic ecosystems, mainly under the influence of anthropogenic factors, the problem of changing the trophic state of water bodies becomes urgent [7].

In order to preserve the natural and cultural heritage, in 1998 the Government of the Kyrgyz Republic decided to establish the Issyk-Kul biosphere zone within the administrative territories of the Issyk-Kul region. The structure of the Issyk-Kul region includes 5 districts and 3 cities. All districts and cities of the region are located around the lake. Since 2013, the number of resident populations of the Issyk-Kul region has increased by 11.3 thousand people. 470.1 thousand people live in the immediate vicinity of the lake [8].

Issyk-Kul Lake in the period of planned economy was used as the main fishing pond of the country, today it is most used as an object of recreation.

Due to the enough reserves of therapeutic mud, geothermal mineral springs, the number of tourists increases every year, as a result, the tourist business is actively developing around the Issyk-Kul lake. Around the lake, resort and recreation complexes, boarding houses and hotels are being built at an accelerated pace. The increase in the number of resort and recreational infrastructures, in turn, increases the anthropogenic load on Lake Issyk-Kul. 
Considering the above, the goal of our research on Lake Issyk-Kul was to study the biological, chemical and physical parameters of the lake water.

\section{Materials and Methods}

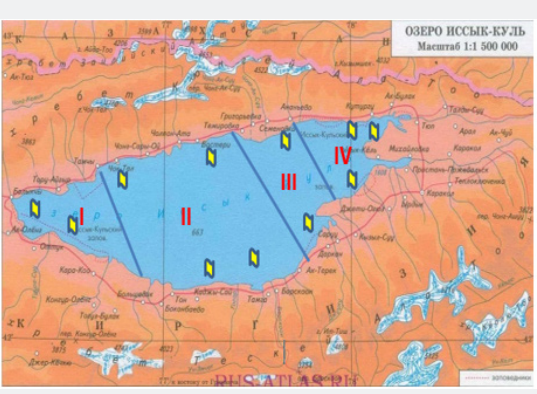

Figure 1: Geographical map of Issyk-Kul lake

For the study, 11 areas of the Issyk-Kul lake were selected, and work was carried out during each 2014-2015 season. Considering the main tributaries of the rivers to the lake, as well as according to the characteristics of the habitat (the presence of protected areas, recreation areas), Issyk-Kul Lake was conventionally divided Research Results and Discussion into four zones, and thus 11 sites were identified for taking water samples for analysis (Figure 1). The sampling strategy included collecting water samples to determine the physicochemical and biological parameters of Lake Issyk-Kul. Water analysis was carried out according to a unified research program using generally accepted methods and rules for selection and analysis.

Rapidly changing physical and chemical parameters of water were measured directly in the water at each allocated area by field portable devices, such as OAKTON DO 110, OAKTON PH 11, Orion Star A 322. The transparency of the water was determined using a Secchi disk. Total and dissolved phosphorus was determined by the method of photometric determination with ammonium molybdate [9]. Chlorophyll- "a" was determined by the spectrophotometric method in the laboratory using the Stirling Kh P [10]. The water quality analysis of Lake Issyk-Kul was carried out using a multidimensional analysis of the main components (PCA principle component analysis). Core Component Analysis (PCA) is a classification method for analyzing a large amount of data received. To perform the PCA, the statistical software package MINITAB (version 16) was used.

Table 1: Physico-chemical and biological parameters of Lake Issyk-Kul (2014-2015)

\begin{tabular}{|c|c|c|c|c|c|c|c|c|c|c|c|c|}
\hline Plot & pH & $\begin{array}{c}\text { Cond } \\
\text { (mS/ } \\
\text { cm) }\end{array}$ & $\begin{array}{c}\text { DO } \\
(\mathrm{mg} / \mathrm{l})\end{array}$ & $\begin{array}{c}\text { TDS } \\
(\mathrm{mg} / \mathrm{l})\end{array}$ & $\begin{array}{c}\text { Sal } \\
(\mathrm{mg} / \mathrm{l})\end{array}$ & $\begin{array}{c}\text { Temp } \\
\left({ }^{\circ} \mathrm{C}\right)\end{array}$ & $\begin{array}{c}\text { TA } \\
(\mathrm{Mg} / \mathrm{l})\end{array}$ & $\begin{array}{c}\text { TP } \\
(\mathrm{Mg} / \mathrm{l})\end{array}$ & $\begin{array}{c}\text { DP } \\
(\mathrm{Mg} / \mathrm{l})\end{array}$ & $\begin{array}{c}\mathrm{No}-3 \\
(\mathrm{Mg} / \mathrm{l})\end{array}$ & $\begin{array}{l}\text { SDD } \\
\text { (M) }\end{array}$ & $\begin{array}{c}\text { Chl-a } \\
\left(\mathrm{mg} / \mathrm{m}^{3}\right)\end{array}$ \\
\hline Kuturgu & 8,8 & 7,1 & 11,1 & 3,4 & 3,8 & 14,4 & 244,7 & 0,02 & 0,014 & 0,135 & 3,3 & 1,2 \\
\hline Mikhaylovka & 8,6 & 7,7 & 11,6 & 3,8 & 4,1 & 13,7 & 252,7 & 0,014 & 0,009 & 0,12 & 2,5 & 0,9 \\
\hline Gray Stroller & 8,8 & 8,0 & 12,3 & 3,6 & 4,1 & 13,3 & 257,5 & 0,018 & 0,012 & 0,14 & 5 & 0,8 \\
\hline Victory & 8,8 & 7,5 & 11,8 & 4,1 & 4,5 & 14,0 & 258,6 & 0,01 & 0,013 & 0,17 & 3,6 & 0,5 \\
\hline Ace & 8,6 & 7,9 & 11,1 & 3,8 & 4,2 & 12,0 & 255,7 & 0,023 & 0,013 & 0,21 & 2,3 & 0,5 \\
\hline Caju Sai & 8,3 & 8,6 & 11,8 & 4,2 & 4,7 & 12,8 & 238,6 & 0,03 & 0,010 & 0,195 & 3 & 0,8 \\
\hline From here & 8,7 & 8,8 & 11,1 & 4,3 & 4,7 & 12,0 & 257,5 & 0,03 & 0,027 & 0,105 & 2,3 & 1,2 \\
\hline Balykchy & 8,7 & 8,8 & 10,4 & 4,3 & 4,8 & 13,5 & 252,8 & 0,03 & 0,027 & 0,135 & 3,5 & 0,9 \\
\hline Kazi fire & 8,7 & 8,6 & 10,7 & 4,2 & 4,7 & 14,1 & 257,9 & 0,01 & 0,013 & 0,142 & 3,5 & 0,8 \\
\hline Bosteri & 8,7 & 8,7 & 10,7 & 4,2 & 4,7 & 14,0 & 254,1 & 0,01 & 0,022 & 0,115 & 3,9 & 0,9 \\
\hline Seed & 8,8 & 8,5 & 10,6 & 4,2 & 4,6 & 13,3 & 259,6 & 0,01 & 0,013 & 0,157 & 3,2 & 0,8 \\
\hline
\end{tabular}

Note: $\mathrm{pH}$ - acid-base water balance, Conductivity - electrical conductivity, Dissolved Oxygen - dissolved oxygen content, TDS - total water salinity, Salinity - salinity, Temperature - temperature, TA - total alkalinity, TP - total phosphorus, DP - dissolved phosphorus, No-3 - nitrates, SDD - water transparency in the depth of the Secchi disk, Chl-a - chlorophyll- "a".

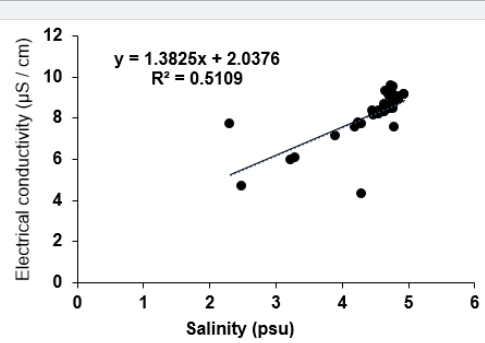

Figure 2: Relationship between electrical conductivity and salinity during all four seasons in 11 sampling sites at Issyk-Kul Lake
Table 1 presents data on the water quality of Lake Issyk-Kul, which were averaged over the seasons and their average values were determined by individual parameters. In order to minimize the effect of large values on the results, all the values of the water quality parameters were transformed in the fourth root [11]. The transformed data was then subjected to PCA analysis (Table 1). When analyzing the data obtained, it was found that the indicators of electrical conductivity and salinity were significantly interrelated; in Issyk-Kul lake, a positive relationship between conductivity and salinity was observed. Thus, in the PCA analysis, the electrical conductivity and salinity were not considered by us in order to 
avoid the double influence of the two parameters on the results. (Figure 2)

The results of PCA data on the water quality of Lake Issyk-Kul are shown in (Table 2). The first four main components (PC1, PC2, PC3 and PC4) explain $85 \%$ of the total variance in the amount of data. Since the first two components explain more than $56 \%$ of the total variance, the obtained two-dimensional PC graph is demonstrative in order to describe the characteristics of the sampling sites, having water quality data. The two-dimensional PCA estimate is shown in Figure 3. On the first PC axis, a positive load was due to high mineralization (TDS), high salinity, high phosphorus content, high content of dissolved phosphorus and high content of chlorophyll a. Accordingly, on the basis of a two-dimensional estimate, the data describing limnological parameters are characteristic for the Ottuk, Balykchy and Bosteri areas. On the other hand, the Kuturgu, Mikhailovka, Boz-Beshik, and Zhenish sites based on the PC-2 were characterized by a high content of dissolved oxygen, a high nitrate content, and a high transparency index. In other words, the latter sites were biologically less productive than those that were positively loaded on the first major axis of the component. (Figure 3)

Table 2: Physico-chemical and biological parameters of Lake Issyk-Kul (2014-2015)

\begin{tabular}{|c|c|c|c|c|}
\hline & PC -1 & PC -2 & PC -3 & PC -4 \\
\hline Eigenvalue & 3.382 & 2.817 & 1.9346 & 0.176 \\
\hline Percentage difference & 0.307 & 0.256 & 0.739 & 0.111 \\
\hline Cumulative difference & 0.307 & 0.564 & 0.148 & 0.85 \\
\hline Variables pH & -0.003 & 0.515 & -0.019 & 0.017 \\
\hline Dissolved oxygen & -0.356 & -0.206 & 0.324 & -0.311 \\
\hline TDS (mineralization) & 0.427 & -0.101 & 0.334 & -0.361 \\
\hline Salinity & 0.419 & -0.075 & -0.100 & -0.515 \\
\hline Temperature & -0.197 & 0.390 & 0.491 & 0.362 \\
\hline Total alkalinity & 0.067 & 0.329 & -0.236 & 0.051 \\
\hline Total phosphorus & 0.342 & -0.331 & -0.091 & 0.111 \\
\hline Dissolved phosphorus & 0.461 & 0.194 & 0.296 & -0.014 \\
\hline Nitrates & -0.248 & -0.386 & 0.063 & -0.508 \\
\hline Water clarity & -0.185 & 0.293 & -0.595 & -0.004 \\
\hline Chlorophyll- "a" & 0.217 & 0.184 & \\
\hline
\end{tabular}

In the table below, the values in bold indicate the positive load on the axes of the main component of the PC.

Fat italic values indicate negative loading of PC scores.

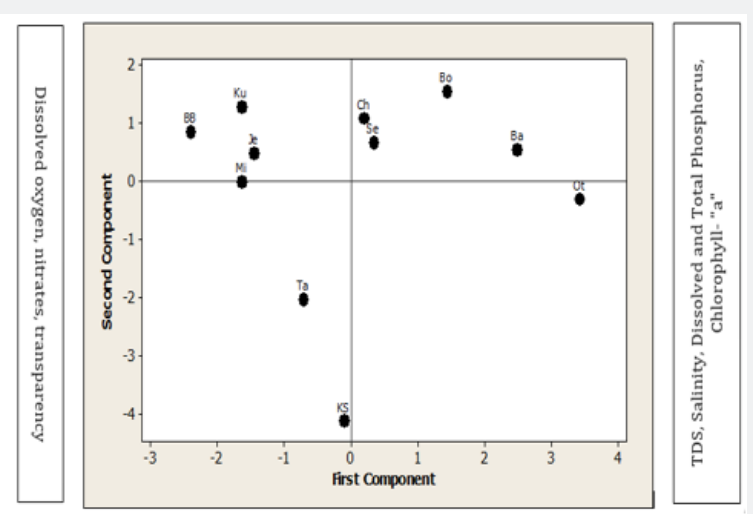

Ku - Kuturgu, Mi - Mikhailovka, BB - Boz-Beshik, Je - Zhenish, Ta - Tamga, KS - Kadji-Sai, Ot - Ottuk, Ba - Balykchy, Ch - Choctal, Bo Bosteri, Se - Semenovka

Figure 3: Two-dimensional PC assessment at 11 water sampling sites at Issyk-Kul Lake by water quality parameters.

\section{Conclusion}

Based on a multidimensional analysis, a quantitative assessment of the parameters of the lake water quality has been obtained, which undergoes some changes in the limnological param- eters of the Issyk-Kul lake. In some parts of the southwestern zone and in the northern part (the Bosteri section) there is a phosphoric load, which is about $0.033 \mathrm{mg} / \mathrm{l}$. Lake Issyk-Kul, being a large, deep-water reservoir, continues to maintain its oligotrophic sta- 
tus in the main part of its water area. However, during the warm seasons of the year, some parts of the lake pass into a mesotrophic body of water.

\section{References}

1. Kitayev SP (2007) Basics of limnology for hydrobiologists and ichthyologists. C: 385.

2. FAO (2016) Fisheries and biological standards for the operation of pond farms in the Kyrgyz Republic.

3. Dmitriev VV, Frumin GT (2004) Ecological regulation and sustainability of natural systems. pp. 294.

4. Mamatkanov DM, Bazhanova LV, Romanovsky VV (2006) Water Resources of Kyrgyzstan. In: Ilim, Kyrgyzstan, p. 265.

5. Berezina N (1963) Hydrobiology. In: Moscow, Russia, pp. 360.
6. Aliyaskarov MA, Sarieva M, Dzhenbaev BM (2018) Determination of the trophic state of Lake Issyk-Kul. Bulletin of the Kyrgyz National Agrarian University named after KI Scriabin 2(47): 256-262.

7. Fruh EG, Stewart KM, Lee GF, Rohlich GA (1966) Measurements of eutrophication and trends. Journal (Water Pollution Control Federation) 38: 1237-1258.

8. National Statistical Committee of the Kyrgyz Republic (2016) Demographic Yearbook of the Kyrgyz Republic 2011-2015.

9. (1977) Manual on chemical analysis of surface water. In: Gidrometeoizdat, Leningrad, Russia, pp. 541.

10. Hadrian P. Stirling (1985) Chemical and Biological Methods of Water Analysis for Aquaculture. Institute of Aquaculture University of Stirling, UK.

11. Quinn G P, Keough M J (2002) Experimental design and data analysis for biologists. In: Cambridge University Press, UK, pp. 537.

Your next submission with Juniper Publishers will reach you the below assets

- Quality Editorial service

- Swift Peer Review

- Reprints availability

- E-prints Service

- Manuscript Podcast for convenient understanding

- Global attainment for your research

- Manuscript accessibility in different formats ( Pdf, E-pub, Full Text, Audio)

- Unceasing customer service

Track the below URL for one-step submission https://juniperpublishers.com/online-submission.php 